\title{
PENGEMBANGAN MODUL IRISAN KERUCUT BERBANTUAN GEOGEBRA
}

\author{
Arta Ekayanti \\ Universitas Muhammadiyah Ponorogo \\ Email: arta_ekayanti@ymail.com
}

\begin{abstract}
The aim of this research was to develop a conic section modul. The modul used GeoGebra in presenting material. This research used development model of Plomp, with three step including preliminary research, prototyping stage and assesment phase. The result of validation test show that modul was valid because contents advisibility, presentation advisibility, graphic advisibility and language advisibility was stay on good level. Analysis of responses quetioner show that modul was practicable because presentation advisibility was in great level and material presenting advisibility and usefulness advisibility was in good level. In other hand, student test show that the modul was effective with score of classical completeness percent was $89.29 \%$. Hence, modul developed satisfied aspect of quality namely valid, practise and effective.
\end{abstract}

Keywords: conic section, ellips, geogebra, hyperbola, parabola

\section{PENDAHULUAN}

Geometri analitik merupakan salah satu mata kuliah yang ada pada prodi matematika maupun pendidikan matematika. Pada mata kuliah ini, diharapkan mahasiswa mampu menguasai beberapa konsep geometri seperti kedudukan titik terhadap garis, garis terhadap garis, garis terhadap bidang serta bidang terhadap bidang. Salah satu pokok bahasan lain yang ada dalam mata kuliah Geometri Analitik adalah Irisan Kerucut.

Irisan kerucut mencakup beberapa pokok bahasan, meliputi parabola, lingkaran, ellips dan hiperbola sebagaimana yang telah disampaikan oleh Beecher (2012). Untuk menguasai pokok-pokok bahasan tersebut, mahasiswa harus memiliki pemahaman yang baik terkait konsepnya terlebih dahulu, selanjutnya diikuti pemahaman dari segi ilustrasi geometrisnya. Karena dua konsep tersebut merupakan komponen utama yang diperlukan dalam upaya menguasai materi yang berkaitan dengan geometri. Sehingga mahasiswa mempunyai kemampuan memvisual-isasikan konsep yang ada dan tidak hanya terpaku pada kemampuan menghitung saja. Proses visualisasi ini dapat ditunjang dengan penggunaan software yang terkait dengan geometri. Salah satu software yang dapat digunakan adalah GeoGebra.

Geogebra merupakan software yang berkenaan dengan konsep matematika khususnya geometri dan aljabar (Hohenwarter: 2008). Software ini banyak dipilih oleh para pengguna karena bersifat open source. Hal ini memungkin para pengguna dengan mudah mengakses ataupun mengunduh software ini, yaitu pada website www.geogebra.com. Software ini sangat mendukung untuk perkuliahan geometri, salah satunya pada bahasan irisan kerucut. Hal ini disebabkan GeoGebra dapat membantu mahasiswa dalam memvisualisasikan konsepkonsep irisan kerucut yang ada. Bahkan menurut Tran dalam Wibowo, Sisworo dan Irawan (2016), GeoGebra selain 
banyak membantu pada proses pembelajaran, GeoGebra juga membantu meningkatkan hasil belajar siswa. Akan lebih efektif, ketika prinsip-prinsip GeoGebra yang digunakan tersebut tertuang dalam buku, handout, modul atau bentuk lain. Sehingga terintegrasi dengan konsep yang ada dalam irisan kerucut.

Modul merupakan seperangkat bahan ajar mandiri yang disajikan secara sistematis sehingga memungkinkan peserta didik belajar sesuai dengan kecepatan belajarnya tanpa tergantung pada orang lain atau dengan bimbingan yang sangat terbatas dari fasilitator/pendidik, apabila diperlukan (Depdiknas, 2004). Khayati (2015) menyebutkan bahwa modul pada dasarnya adalah salah satu bahan ajar yang disusun secara sistematis dan bertahap yang dapat dijadikan sebagai pengganti fungsi pendidik untuk membimbing peserta didik menguasai materi yang diajarkan sesuai dengan kecepatan belajar setiap peserta didik. Hal ini memungkinkan peserta didik untuk belajar mandiri tanpa adanya batas waktu serta tidak bergantung pada pengawasan pendidik. Disamping itu, modul juga sangat mendukung peserta didik dalam rangka mendapatkan pemahamannya sendiri. Hal ini disebabkan karena modul memuat sekumpulan bahan pembelajaran, mekanisme komunikasi dan interaksi, tugas-tugas spesifik serta komponen evaluasi (Depdiknas: 2004).

Pada Program Studi Pendidikan Matematika FKIP Universitas Muhammadiyah Ponorogo, mata kuliah Geometri Analitik diberikan pada semester 2. Berdasarkan observasi, mahasiswa yang menempuh mata kuliah ini cenderung masih sering mengeluh karena kesulitan dalam mengikuti mata kuliah ini. Hal ini karena mahasiswa masih cenderung lebih suka menghitung dari pada pendalaman konsep serta ilustrasi grafis. Mahasiswa masih mengalami kesulitan dalam membayangkan bentuk-bentuk geometri terutama pada pokok bahasan irisan kerucut. Disamping itu, mahasiswa mengeluhkan tidak tersedianya referensi yang menggunakan Bahasa Indonesia. Selama ini, referensi yang digunakan berbahasa Inggris, hal tersebut dianggap sebagai suatu kendala tersendiri bagi mahasiswa.

Berdasarkan latar belakang di atas, diketahui bahwa mahasiswa membutuhkan GeoGebra untuk membantu pemahaman visualisasi geometrisnya. Disamping itu, mahasiswa membutuhkan referensi yang berbahasa Indonesia,sehingga memungkinkan bagi mereka untuk belajar mandiri. Oleh karena itu, dilakukan penelitian dan pengembangan yang ber-judul Pengembangan Modul Irisan Kerucut Berbantuan GeoGebra pada Mata Kuliah Geometri Analitik.

\section{METODE PENELITIAN}

Penelitian ini dilakukan dengan menerapkan metode penelitian dan pengembangan (Research and Development). Menurut Sugiyono (2015), metode penelitian dan pengembangan merupakan metode penelitian yang digunakan untuk menghasilkan produk tertentu dan menguji keefektifan produk tersebut.

Penelitian pengembangan ini diadaptasi dari model yang dikemukakan oleh Plomp (2010). Tahap pengembangan tersebut terdiri atas 3 tahap yaitu:

\section{Tahap Pendahuluan (Preliminary research)}

Pada tahap ini, dianalisis potensi dan masalah, membuat draft garis besar konten yang akan di bahas, mengembangkan kerangka kerja penelitian sehingga menghasilkan 
modul irisan kerucut berbantuan GeoGebra.

\section{Tahap pembuatan prototipe} (Prototyping stage)

Pada tahap ini, dikembangkan modul irisan kerucut berbantuan GeoGebra berdasarkan draft garis besar konten yang akan di bahas sebagaimana telah dilakukan pada tahap pertama, merevisi instrumen awal yang telah dikembangkan melalui penilaian ahli.

\section{Tahap penilaian (Assesment phase)}

Selanjutnya, pada tahap ini diujicoba modul yang telah dikembangkan kepada mahasiswa.

Kualitas modul yang dikembangkan dikatakan baik apabila telah memenuhi kriteria valid, praktis dan efektif. Untuk kevalidan modul dilihat dari hasil validasi modul oleh para ahli, baik itu ahli media maupun ahli materi. Modul dikatakan valid apabila telah mencapai kategori baik atau sangat baik pada penilaian setiap aspek. Kriteria kepraktisan modul dilihat dari tanggapan atau respon mahasiswa terkait penggunaan modul dalam proses pembelajaran. Modul dikatakan praktis apabila, respon mahasiswa mencapai kriteria baik atau sangat baik.

Berikut langkah-langkah untuk menentukan pengkategorian kevalidan maupun kepraktisan modul.

1. Mencari skor minimum $\left(S_{\min }\right)$ dan skor maksimum $\left(S_{\text {maks }}\right)$

2. Mencari rentang $(R)$ yaitu $R=S_{\text {maks }}-S_{\text {min }}$

3. Menetapkan panjang interval $(p)$ dengan menggunakan 4 kategori yaitu

$$
p=\frac{R}{4}
$$

4. Menetapkan tabel kriteria penilaian sebagai berikut

Tabel 1. Rentang Persentase Validitas Mahasiswa

\begin{tabular}{|c|c|}
\hline Interval \% skor & Kriteria \\
\hline$S_{\text {maks }}-p \leq S \leq S_{\text {maks }}$ & Sangat baik \\
\hline$S_{\text {maks }}-2 p \leq S<S_{\text {maks }}-p$ & Baik \\
\hline$S_{\text {maks }}-3 p \leq S<S_{\text {maks }}-2 p$ & Kurang \\
\hline$S_{\text {min }} \leq S<S_{\text {maks }}-3 p$ & Sangat Kurang \\
\hline
\end{tabular}

5. Mencari skor respon mahasiswa $S$, yaitu

$S=$ jumlah skor kriteria tertentu

Untuk selanjutnya dicocokkan dengan tabel kriteria penilaian.

Kriteria keefektifan modul dilihat dari hasil belajar mahasiswa. Modul dikatakan efektif apabila media ketuntasan klasikal mahasiswa mencapai kriteria baik atau sangat baik. Dalam menentukan persentase ketuntasan mahasiswa secara klasikal digunakan formula sebagai berikut:
Keterangan:

$$
p=\frac{\Sigma n_{i}}{\Sigma n} \times 100 \%
$$

$p$ : persentase ketuntasan belajar secara klasikal

$\Sigma n_{i}$ : jumlah mahasiswa yang tuntas secara individual

$\Sigma n$ : jumlah mahasiswa keseluruhan

Adapun penilaian kualitas hasil belajar diperoleh dengan mengkonfirmasikan persentase ketuntasan klasikal dengan parameter sebagai berikut: 
Tabel 2. Rentang Persentase Ketuntasan Klasikal

\begin{tabular}{|c|c|}
\hline Interval $\%$ Skor & Kriteria \\
\hline $75 \%<p \leq 100 \%$ & Sangat baik \\
$50 \%<p \leq 75 \%$ & Baik \\
$25 \%<p \leq 50 \%$ & Kurang baik \\
$p \leq 25 \%$ & Tidak baik \\
\hline
\end{tabular}

\section{HASIL PENELITIAN DAN PEMBAHASAN \\ Pengembangan Modul}

Pengembangan modul irisan kerucut ini mengacu pada langkahlangkah penelitian pengembangan menurut Plomp (2010). Hal ini dapat dilihat pada paparan berikut ini:

1. Tahap Pendahuluan (Preliminary research)

Terbatasnya referensi materi irisan kerucut yang berbahasa Indonesia, serta terbatasnya kemampuan mahasiswa dalam memvisualisasikan bentuk-bentuk geometri seperti irisan kerucut dirasa menjadi kendala tersendiri pada proses pem-belajaran mata kuliah geometri analitik.
Oleh karena itu, perlu dikembangkan modul irisan kerucut berbantuan GeoGebra. Dari masing-masing irisan kerucut, pembahasan akan diawali dengan formula-formula yang berlaku, serta asal mula formula tersebut. Selanjutnya diikuti penjelasan materi irisan tersebut dengan fasilitas GeoGebra. Didalamnya dijelaskan bagaimana cara menampilkan gambar dari irisan kerucut serta menentukan kompo-nen-komponen yang ada pada masing-masing irisan kerucut.

2. Tahap pembuatan prototipe (Prototyping stage)

Pada tahap ini, disusun modul irisan kerucut dengan garis besar komponen modul sebagai berikut:

Tabel 3. Komponen Modul

\begin{tabular}{|l|l|}
\hline \multicolumn{1}{|c|}{ Struktur Modul } & \multicolumn{1}{c|}{ Keterangan } \\
\hline Bagian Pendahuluan & Sampul, kata pengantar, daftar isi, CP Mata Kuliah. \\
\hline Bagian Isi & Judul, uraian materi (dilengkapi selidiki), latihan soal. \\
\hline Bagian Akhir & Daftar Pustaka \\
\hline
\end{tabular}

Setelah modul tersusun, selanjutnya modul diserahkan kepada ahli yang berkompeten guna untuk keperluan validasi. Masukan dari validator sangat diharapkan untuk memperbaiki modul.

3. Tahap penilaian (Assesment phase)

Selanjutnya, pada tahap ini diujicoba modul yang telah dikembangkan kepada mahasiswa. Dari tahapan ini akan diperoleh tanggapan mahasiswa terkait modul irisan kerucut yang digunakan. Serta kebermanfaatan dari modul, hal ini dilihat dari hasil belajar mahasiswa setelah mengikuti kegiatan pembelajaran dengan fasilitas modul irisan kerucut.

Validasi Modul

Setelah modul tersusun, selanjutnya dilakukan validasi yang melibatkan para ahli, yaitu ahli materi dan ahli media.

Dari segi materi, aspek yang dinilai meliputi aspek kelayakan isi dan kelayakan penyajian. Hasil validasi dari ahli materi menunjukkan aspek kelayakan isi mendapatkan skor 29 dari skor maksimal 40. Hasil ini menunjukkan bahwa, jika ditinjau dari aspek kelayakan isi modul mencapai 
kategori baik. Selanjutnya jika ditinjau dari aspek kelayakan penyajian, diperoleh skor 20 dari skor maksimal 28. Artinya modul telah mencapai kategori baik. Data analisis hasil validasi dari ahli materi dapat dilihat pada Tabel 4.

Tabel 4. Hasil Validasi Ahli Materi

\begin{tabular}{|c|c|c|c|}
\hline \multicolumn{1}{|c|}{ Aspek } & Skor yang diperoleh & Skor Maksimal & Kategori \\
\hline Kelayakan Isi & 29 & 40 & Baik \\
Kelayakan Penyajian & 20 & 28 & Baik \\
\hline
\end{tabular}

Lebih lanjut, jika ditinjau dari segi media aspek yang dinilai meliputi aspek kelayakan kegrafikan dan kelayakan bahasa. Skor yang diperoleh untuk aspek kelayakan kegrafikan adalah 28 dari skor maksimal 36. Hal ini menunjukkan bahwa dari aspek kelayakan kegrafikan mencapai kategori baik. Sedangkan dari aspek kelayakan bahasa, diperoleh skor 31 dari skor maksimal 40. Dengan kata lain, jika dilihat dari aspek kelayakan bahasa, modul termasuk pada kategori baik. Dengan demikian, karena dari segala aspek penilaian modul telah mencapai kategori baik maka modul dapat dikatakan valid. Adapun data analisis hasil validasi secara lengkap dapat dilihat pada Tabel 5.

Tabel 5. Hasil Validasi Ahli Media

\begin{tabular}{|l|c|c|c|}
\hline \multicolumn{1}{|c|}{ Aspek } & Skor yang diperoleh & Skor Maksimal & Kategori \\
\hline Kelayakan Kegrafikan & 28 & 36 & Baik \\
Kelayakan Bahasa & 31 & 40 & Baik \\
\hline
\end{tabular}

\section{Uji Coba Modul}

\section{Respon Mahasiswa}

Untuk mengetahui respon mahasiswa terkait modul yang diberikan, digunakan angket respon mahasiswa. dari angket yang digunakan terdapat tiga aspek yang diperhatikan, yaitu aspek tampilan, penyajian materi dan manfaat. Skor yang diperoleh untuk aspek tampilan modul adalah 365 dari skor maksimal 448. Untuk skala empat, nilai tersebut termasuk dalam kategori sangat baik. Sedangkan untuk aspek penyajian materi, skor yang diperoleh adalah 509 dari skor maksimal 672. Hal ini menunjukkan bahwa modul termasuk pada kategori baik ketika ditinjau dari aspek penyajian materi. Lebih lanjut, ketika ditinjau dari aspek manfaat modul diperoleh skor 442 untuk skor maksimal 560. Untuk nilai tersebut, modul termasuk pada kategori baik. Dengan demikian, modul dikatakan memenuhi kriteria praktis. Hal ini sesuai dengan penelitian yang telah dilakukan oleh Khayati (2015), bahwasanya pembelajaran dengan menggunakan modul memberikan respon yang positif bagi siswa. Adapun untuk hasil analisis angket respon mahasiswa dapat dilihat pada Tabel 6 berikut: 
Tabel 6. Hasil Analisis Respon Mahasiswa

\begin{tabular}{|l|c|c|c|}
\hline \multicolumn{1}{|c|}{ Aspek } & Skor yang diperoleh & Skor Maksimal & Kategori \\
\hline Tampilan & 365 & 448 & Sangat baik \\
Penyajian Materi & 509 & 672 & baik \\
Manfaat & 442 & 560 & baik \\
\hline
\end{tabular}

\section{Hasil Belajar Mahasiswa}

Setelah mengikuti proses pembe-lajaran dengan fasilitas modul irisan kerucut, selanjutnya dilakukan tes untuk melihat ketuntasan belajar mahasiswa. ringkasan data hasil belajar mahasiswa diberikan pada Tabel 7 berikut.

Tabel 7. Data Hasil Belajar Mahasiswa

\begin{tabular}{|l|c|}
\hline \multicolumn{1}{|c|}{ Hasil Belajar } & Ketercapaian \\
\hline Rata-rata & 86.43 \\
\hline Jumlah Mahasiswa & 28 \\
\hline Nilai tertinggi & 100 \\
\hline Nilai terendah & 72 \\
\hline Mahasiswa tuntas & 25 \\
\hline Mahasiswa tidak tuntas & 3 \\
\hline Ketuntasan klasikal (kriteria) & $89.29 \%$ (sangat baik) \\
\hline
\end{tabular}

Jumlah mahasiswa yang tuntas sebanyak 25 dari total keseluruhan 28 mahasiswa. Persentase ketuntasan belajar mahasiswa secara klasikal mencapai $89,29 \%$ termasuk dalam kriteria "sangat baik" dengan rata-rata nilai 86.43. Hasil ini menunjukkan bahwa modul telah mencapai kriteria efektif. Dengan demikian modul berbantuan GeoGebra ini memberikan dampak yang positif terhadap hasil belajar siswa, hal ini sejalan dengan pendapat Tran dalam Wibowo, Sisworo dan Irawan (2016), bahwa GeoGebra selain banyak membantu pada proses pembelajaran, GeoGebra juga membantu meningkatkan hasil belajar siswa

\section{KESIMPULAN DAN SARAN}

Penelitian pengembangan ini telah menghasilkan modul yang memenuhi kriteria valid, praktis dan efektif. Kevalidan modul tercapai sebab dari seluruh aspek penilaian yaitu aspek kelayakan isi dan penyajian yang merupakan penilaian dari segi materi, keduanya mencapai kategori baik. Sedangkan dari segi media, kedua aspek penilaian yaitu kelayakan kegrafikan dan kelayakan bahasa keduanya termasuk pada kategori baik. Kepraktisan modul dapat dilihat dari hasil analisis respon mahasiswa yang memuat tiga aspek penilaian yaitu tampilan, penyajian materi dan manfaat. Dari aspek tampilan modul termasuk pada kategori sangat baik, sedangkan ditinjau dari aspek penyajian materi dan manfaat modul termasuk pada kategori baik. Keefektifan tercapai sebab persentase ketuntasan klasikal sebesar $89.29 \%$ yang termasuk pada kategori sangat baik.

Saran dalam penelitian adalah penelitian ini masih terbatas pada materi irisan kerucut. Selanjutnya akan lebih baik jika materi dikembangkan ke bahasan-bahasan geometri lainnya. Hal ini dirasa perlu karena untuk membantu mahasiswa dalam memvisualisasikan bentuk-bentuk geometri, sehingga dapat 
ISSN 2089-8703 (Print) Vol. 6, No. 3 (2017)

ISSN 2442-5419 (Online)

dilakukan pada penelitian-penelitian selanjutnya.

\section{DAFTAR PUSTAKA}

Beecher, P. B. 2012. Algebra and Trigonometry. USA: Pearson Education, Inc.

Depdiknas. 2004. Pedoman Khusus Penyusunan Modul Sekolah Menengah Atas. Jakarta. Depdiknas.

Hohenwarter, M. 2008. Teaching and Learning Calculus with Free Dynamic Mathematics Software GeoGebra. USA. Florida Atlantic University, research and development in the teaching and learning of calculus ICME 11, Monterrey, Mexico 2008.

Khayati, F. 2015. Tesis. Pengembangan Modul Matematika untuk Pembelajaran Berbasis Masalah (Problem Based Learning) Pada Materi Pokok Persamaan Garis Lurus Kelas VIII SMP. Universitas Sebelas Maret Surakarta.

Plomp, T. 2010. An Introduction to Educational Design Research. Netherlands: SLO

Sugiyono, 2015. Metode Penelitian Pendidikan. Bandung: Alfabeta

Wibowo, A. W. H., Sisworo, dan Irawan, E. B. 2016. Prosiding Seminar Nasional Matematika dan Pembelajarannya 2016. Visualisasi Volume Benda Putar Menggunakan Animasi GeoGebra untuk Mening-katkan Kemampuan Representasi Matematis Siswa. Universitas Negeri Malang. 